sciendo Порівняльна професійна педагогіка 8(3)/2018

Comparative Professional Pedagogy 8(3)/2018

DOI: $10.2478 /$ rpp-2018-0046

Postgraduate Student, ALLA SAMKO

Ivan Ziaziun Institute of Pedagogical and Adult Education of The National Academy of Pedagogical Sciences of Ukraine Address: 9 M. Berlynskyi, Kyiv, 04060, Ukraine E-mail: alla-samko@ukr.net

\title{
UKRAINIAN AND FOREIGN EXPERIENCE IN APPLYING BIOGRAPHICAL METHOD TO STUDY PROMINENT FIGURES IN PEDAGOGY
}

\begin{abstract}
The article analyzes the term "biographical method", which consists in the idea of a biography being one's life journey. Its essence was disclosed through the views of the leading Ukrainian and foreign scholars. The origins of the biographical method as the main tool for studying prominent figures in pedagogy were specified. The article contains the domain-specific classification of biographical sources including autobiographies, biographies, life stories, personal experience stories, surveys and interviews, public and private archival materials, printed and hand-written heritage of authors, memoirs of their contemporaries, etc. Specific attention is paid to the fact that biographical researches can characterize the course of life of a particular figure in pedagogy, the era in which he/she lived and worked, the process of shaping and developing his/her worldview and pedagogical views. Consequently, one can highlight the main stages in the pedagogue's life, better understand the essence of his/her cultural, educational activities, grasp his/her unique identity, reveal certain patterns in various facts of his/her biography that have caused the emergence and development of particular educational and pedagogical ideas. Based on theoretical analysis of the works by Ukrainian and foreign scholars, it was concluded that the biographical method could determine the influence of society on the development of the individual, his/her life position, values and ideals, different moments of the society's life at one time period or another, social contexts, rules and norms. It was found that when studying the biographies of prominent figures in pedagogy one should be able to balance the given material on the pedagogue's activities, the description of his/her works and theoretical analysis and understanding of the trends in the development of his/her views and a reasonable assessment of his/her contributions.
\end{abstract}

Keywords: biographical method, biographical studies, historical and biographical researches, pedagogical figure, scientific biography, resources.

\section{INTRODUCTION}

The modern development of historical and pedagogical science is characterized by a constructive, scientifically objective and thorough study of a pedagogical biography and heritage of prominent figures in pedagogy, as well as the Ukrainian and foreign scientific and pedagogical experience. Historical and biographical researches occupy a significant place in the history of science and contribute to personifying the development history of its branches, assessing contributions of the scholars and individuals involved in scientific researches and organization of science. Therefore, the Ukrainian pedagogical thought can be revived and the unity and continuity of generations can be ensured due to a profound study of the Ukrainian pedagogical heritage and a scientific analysis of the Ukrainian pedagogues' ideas and views. 


\section{THE AIM OF THE STUDY}

The research aims to justify the views of the leading Ukrainian and foreign scholars on the role of the biographical method in studying prominent figures in pedagogy and to analyze the classification of biographical researches.

\section{THEORETICAL FRAMEWORK AND RESEARCH METHODS}

In the context of scientific discourse, the biographical method was studied by such Ukrainian scholars as H. Bielan (2013a; 2013b), V. Onopriienko (2010), I. Rozman (2017), L. Smolinchuk (2013), O. Sukhomlynska (2005) et al. Some significant experience in the field of scientific biographical studies was also systematized by foreign scholars including N. Denzin (1989), P. Dominice (2006), E. Dubas (2009), W. Fuchs-Heinritz (1993), S. Lee (1918), B. Roberts (2002), J. Roos (1997), E. Skibińska (2006).

The current research summarizes the findings obtained by a set of theoretical methods such as induction and deduction (used to collect theoretical and factual material and generalize it), comparative analysis and synthesis (used to specify the content of the main concepts and terms).

\section{RESULTS}

One of the priority areas in the modern historical and pedagogical science consists in studying the figures in pedagogy, who represent exceptional pedagogical achievements and contribute to developing views on a holistic pedagogical process. Nowadays, the processes of disclosing pedagogical views of scholars, pedagogues, cultural figures of the past and studying their creative biographies in the context of the historical epoch allow reconstructing the phenomena and facts of historical and pedagogical science. Therefore, the biographical method will be of importance when analyzing the historical and pedagogical phenomena of a certain time period.

The increasing interest of pedagogy in biographical studies is associated with the emergence of new methods for assessing the quality of pedagogical studies. Since the 1980s, many countries (the UK, the USA, Germany, Poland, etc.) have been widely employing the rapidly developing biographical studies, which today serve as a platform for various pedagogical studies.

The biographical method was first scientifically justified by the representatives of the Chicago School of American Sociology in the 1920-30s. It was mostly defined by such traditional concepts in the professional English-speaking community as biographical perspective and biographical approach. The essence of these concepts was rooted in the method's complexity, which included a set of sociological methods, namely empirical observation, objective analysis of biographical facts, their interpretation and generalization, etc. (Bielan, 2013a, p. 51). Indeed, H. Bielan (2013a) indicates that the biographical method primarily aims to study the life of an individual, connected with his/her immediate environment, microenvironment and his/her subjective views on the life and social reality of his/her environment.

It is found that the term "biography" originates from the Greek ßío $\varsigma$ "life" and póp $\omega$ "record, account" (Online Etymology Dictionary, 2018). The biographers of prominent figures of the past sought to describe the sociohistorical conditions under which one individual or another lived as accurately as possible and to outline the main creative achievements of a particular figure taking into account the factors which influenced the development of his/her personality and views (Bielan, 2013a, p. 51). If successfully performed, these actions allowed the biographers to create rather a clear "portrait in the background", which outlined the widest possible range of probable relations and patterns, thus providing the next generation of researchers with the right to interpret their significance. 
sciendo Порівняльна професійна педагогіка 8(3)/2018

Comparative Professional Pedagogy 8(3)/2018

S. Lee (1918), the English 20th-century researcher in the field of scientific biography, indicated, "The emergence of a biography can be traced to the beginning of mankind since there always existed the need to satisfy the ancient instinct - the recordative one. People are eager to preserve the memory of those who, by words and deeds, stood out from the crowd, were respected by their contemporaries and are still able to attract the interest of future generations" (p. 10).

Foreign biographical studies focus on prominent figures in a particular field, their roles in the sociocultural environment, experiences, views and contributions to culture or science and set different scientific goals. However, they always provide a holistic picture of their lives, take into account and disclose the interconnection between an individual history and the history of society, present certain culturological generalizations and conclusions. According to the German scholar W. Fuchs-Heinritz (1993), many human sciences in France, Canada, Italy and other countries have acquired an interest in the biographical method since the late 1970s and as a result "research interests of rather different theoretical traditions have overlapped and today represent a well-developed and international area of biographical research" (p. 16).

The Ukrainian historical and pedagogical science relies on O. Sukhomlynska's views on the role of the biographical method in studying prominent figures in pedagogy. "In order to personify and systematically outline the development of the Ukrainian pedagogical thought as a non-linear, multidimensional process of qualitative changes through creative biographies of the pedagogues whose views, beliefs, and ideas have become the driving force behind the overall process of pedagogical science development," she stressed, "it is imperative to be in possession of appropriate tools" (Sukhomlynska, 2005, p. 5).

O. Sukhomlynska (2005) believes that a list of the approaches and methods used to systematically analyze the historical and pedagogical phenomena of a particular time period must include the biographical method. The scholar defines it as a way of processing the sources in which an individual biography and personality of the pedagogue act as a factor in his/her work and reflect or create his/her era. The main function of this method in historical and pedagogical science is rooted in the search for the causes of emergence and development of pedagogical ideas in various facts of the biography and the relevation of those essential, "iconic" moments that allow identifying certain patterns in the accumulation of empirical facts about one individual or another (Sukhomlynska, 2005, p. 5).

In modern practice, the term "biographical method" has a wide range of meanings and senses. H. Bielan (2013a) defines the biographical method as "the leading tool for studying prominent figures in pedagogy" since "it considers pedagogical reality in time and space and discloses the problem in the historical cultural context" (p. 52). According to V. Onopriienko (2010), the biographical method is a specific conceptual approach to studying a prominent figure based on the notion that an individual is a "product" of his/her own biography or history of his/her life, that is "the biography is one's life journey" (p. 133). W. Fuchs-Heinritz (1993) defines the biographical method as a way of measuring and assessing some real life and historical evidence (p. 12). When identifying the biographical method as a way of collecting and using some documentary evidence that describes the turning points of an individual life, the English sociologist N. Denzin (1989) concludes, "it involves some experiences of an individual, a group or an organization in the form through which they can interpret these experiences" (p. 7).

The biographical method in historical and pedagogical science is considered as a combination of ways and means of organizing and conducting researches on individual 
biographies based on accumulation, analysis, interpretation of any possible and accessible sources of information. The object of the biographical method is to study a life's journey of a prominent figure and present it in the form of a chronological sequence of the facts from the personal biography, which includes the stages of ideological and spiritual development, professional and creative achievements (Rozman, 2017, p. 98). The subject of the biographical method includes the patterns and mechanisms which determine and regulate the individual's living as a self-sufficient process.

Nowadays the biographical method as a new instrument of sociological research is becoming more and more popular. Also it serves as the basis for a whole new area of biographical studies in the field of sociology in Poland and psychology in Austria. In addition, biographical studies are applied not only to sociological and psychological sciences, but are also transformed into a range of historical, literary, historical and pedagogical science. As a result of these processes there appears a separate field of scientific knowledge about an individual - the biography, whose object of study is a prominent figure together with his/her diverse relationships with society, which is considered in the synthesis of individual and unique and social aspects (Bielan, 2013a, p. 51). As a separate branch of science, the biography acquires an interdisciplinary status and is based on the methodology of such sciences as psychology, sociology, philosophy, history, literary studies and, most importantly, the history of pedagogy.

In the context of the current research, it is important to distinguish another aspect of the biographical method, namely the main biographical sources, which should contain comprehensive and objective information about the main stages in the individual's life. A source base is a collection of systematized and classified sources, which contain some information about the pedagogical past. The source base of biographical studies on the history of pedagogy are scientific, journalistic, historical works, documentary materials (in particular, correspondence, diaries, autobiographies) and other historical and pedagogical sources, which contain authentic informative and substantive facts about the originality and uniqueness of the time period under study (Bielan, 2013b, p. 30).

It should be noted that there is some divergence in the views of modern researchers in the field of sociology and biography on the prioritization of using primary (an oral narrative) and secondary (written, documentary) sources of a biographical material. B. Roberts (2002) considers the biographical material to be any verbal or written narrative made by the individual about the events of his/her life. The scholar believes that under certain conditions "life stories" can be reproduced based on such secondary sources as official documents, letters, memoirs of other individuals, etc. (Roberts, 2002). W. Fuchs-Heinritz (1993) considers oral narratives about one's own life to be the most reliable biographical source (p. 12). N. Denzin (1989) gives priority to documentary sources, namely autobiographies, biographies, obituaries, life stories and stories about personal experience (p. 7). The Finnish sociologist J. Roos (1997) believes that an autobiography as a source of biographical facts is an author's project, which presents the main moments of the author's life through the prism of his/her personal perception (p. 9). Polish sociologists, however, distinguish between the concepts of autobiography and biography. According to E. Skibińska (2006), the autobiography is a product of an individual's activity, which reveals its subjective character and depends on the individual's perception. It is a continuous process immersed in all kinds of contexts, namely temporal, spatial, social and cultural ones. The concept of the biography is interpreted by the scholar as "a life report". The biography contains an objective description 
of facts, events and individuals, as well as a description of the subjective values specified in these facts, events and individuals (Skibińska, 2006, p. 330). On the other hand, P. Dominice (2006) argues that both biographies and autobiographies contain a life story, whose author is believed to be its main character. According to this approach, the biography arises from its researcher's inspiration, whereas the autobiography - from the needs of the author himself/herself (Skibińska, 2006, p. 13). According to E. Dubas (2009), the biography is a construction of thinking, which organizes, interprets and gives meaning to the experience gained by the individual throughout his/her life (p. 41). The biography contains memories about life experiences, events and situations experienced by the individual, which are usually rather important and significant since they have influenced him/her throughout his/her life.

Modern researchers include to biographical sources the following materials: official documents of a particular individual, which contain the information about his/her place of birth, education and educational attainments, which have affected his/her further professional realization; reference and statistical documents with his/her biographical data and personal characteristics; genealogical sources: a genealogical tree, family legends; autobiographical materials, which usually contain some authentic information about the origin, merital status, education, career, creative achievements; some family correspondence, which contains some unique information about the individual, his/her acquaintances, interests, activities, hobbies, inner world; scientific and artistic works of the prominent scholars and artists as a form of personal self-expression; memoirs; personal diaries (Bielan, 2013b, p. 30). A complete and objective description of the life of one individual or another will only ensure comprehensive use of all the sources in their comparative and analytical dimension.

Since the main goal of biographical studies in modern historical and pedagogical science is to create an objective genuine portrait of the pedagogue's personal development, one should consider an important role of such components as his/her genealogical origin, family environment and education, family traditions and atmosphere, their influence on the development of his/her worldview; the ways and stages of his/her personality development (places of study, fields of interests, relationships, etc.); the factors in the development of his/her worldview, intellectual abilities, temperament, inner beliefs; his/her interactions with other individuals; the influence of the surrounding individuals or, vice versa, a particular individual on them; the motives of the most famous acts, which have put the individual's name in history; the influence of external factors; the justification of ups and downs in the lives of creative people through certain life circumstances; some significant events in his/her private life (marriage, childbirth), their influence on the main (scientific, creative, social, political) activity; his/her physical and psychological well-being in different periods of life and their influence on some individual episodes of his/her activity; his/her contemporaries' objective and subjective characteristics of himself/herself; his/her financial situation, dependence on financial circumstances and their influence of his/her creative activity (Bielan, 2013b, p. 30). However, all the data can be collected only from reliable, diverse sources, which form the basis of biographical studies in the field of historical and pedagogical science.

It should be noted that one of the components of the studies on a prominent figure in pedagogy is the analysis of his/her pedagogical heritage. This element of historical and pedagogical studies consists in analyzing another sources, primarily the pedagogue's creative heritage, which is represented by journalistic and scientific works (monographs, reports, articles, lectures, reviews, etc.). Such materials as drafts, observation diaries, notes from other scholars' works are also of importance since they justify the evolution of the 
pedagogue's views and fully disclose their essence (Smolinchuk, 2013, p. 667). These views are occassionally reflected in the content of school or university textbooks, other manuals for pupils, students or methodological aids for teachers, which reflect the relevant recommendations for the content and methods of teaching and learning. The sources under study can be classified with the help of such theoretical methods as analysis, synthesis, generalization.

In addition, the logic of any historical and pedagogical research always requires a classification of sources. In this case, pedagogical heritage can be classified according to specific domains such as either particular branches of science (the history of didactics, the theory of education, methodology, school education, etc.) or types, levels, fields of education (the history of general and special education; primary, secondary, higher education; vocational education; medical education; military education, etc.) (Smolinchuk, 2013, p. 667). Such an approach to classifying allows researchers to comprehensively and systematically present the history of various pedagogical problems that were of importance to the prominent figure in pedagogy whose biography is under study.

It is also necessary to classify this group of sources in terms of content characteristics, taking into account only scientific researches (monographs, scientific articles, dissertations), promotional works (journalism, popular science publications), educational sources (manuals, textbooks), reference sources (encyclopedias, bibliographical references, dictionaries, etc.), selected sources (collections of documents, publication of works, etc.). Such classifications supplement pedagogues' biographies due to defining the main areas of their activities at different life stages. A chronological approach should be also used to classify different biographical sources since it chronologically presents the processes of shaping and developing the views of the pedagogue under study on a particular problem (Smolinchuk, 2013, p. 667).

\section{CONCLUSIONS}

So, having analyzed the works of Ukrainian and foreign scholars, it can be concluded that the biographical method can determine the influence of society on the development of the individual, his/her life position, values and ideals, different moments of the society's life at one time period or another, social contexts, rules and norms. When studying the biographies of prominent figures in pedagogy, one should be able to balance the given material on the pedagogue's activities, the description of his/her works and theoretical analysis and understanding of the trends in the development of his/her views and a reasonable assessment of his/her contribution.

The current research does not disclose all the aspects of the problem. Further researches should deal with the problem of incorporating biographical sources in research activities, as well as applying the biographical method to pedagogical biographical studies.

\section{REFERENCES}

1. Bielan, H. V. (2013a). Biohrafichnyi metod v istoryko-pedahohichnii nautsi: providni tendentsii stanovlennia. Pedahohichnyi dyskurs, 15, 50-54.

2. Bielan, H. V. (2013b). Do pytannia pro dzherela biohrafichnykh doslidzhen v istoryko-pedahohichnii nautsi. Pedahohichni nauky, 64, 28-31.

3. Denzin, N. (1989). The Research Act. A theoretical introduction to sociological methods. Englewood Cliffs, NJ: Prentice Hall.

4. Dominice, P. (2006) Uczyć się z życia. Biografia edukacyjna w edukacji dorostych. Łódź: Wydawnictwo Wyższej Szkoły Humanistyczno-Ekonomicznej w Łodzi. 
5. Dubas, E. (2009). Refleksja autobiograficzna jako aktywność edukacyjna w kontekście całożyciowego uczenia się. In A. Fabiś and S. Kędziora (Eds.), Aktywność spoleczna, kulturalna i oświatowa dorostych (pp. 41-53). Mysłowice; Zakopane: Górnośląska Wyższa Szkoła Pedagogiczna w Mysłowicach.

6. Fuchs-Heinritz, W. (1993). Biograficheskii metod. V V. Semenova i E. Meshcherkina (Red.), Biograficheskii metod v sotsiologii: istoriia, metodologiia, praktika (S. 11-41). Moscow: Institut sotsiologii RAN.

7. Lee, S. (1918). The perspective of biography. London: The English Association.

8. Online Etymology Dictionary. (2018). Biography. Retrieved from https://www. etymonline. com/word/biography\#etymonline_v_11172.

9. Onopriienko, V. Y. (2010). Biograficheskii metod v psikhologii i sotsyologii. Visnyk Natsionalnoho aviatsiinoho universytetu. Seriia: Filosofiia. Kulturolohiia, 2, 130-136.

10. Roberts, B. (2002). Biographical research principles and practice in survey research. Retrieved from http://mcgraw-hill.co.uk/openup/chapters/0335202861.pdf.

11. Roos, J. P. (1997). Kontekst, autentichnost, referentsialnost, refleksivnost: nazad k osnovam avtobiografii. V V. Voronkov i E. Zdravomyslova (Red.), Biograficheskii metod v izuchenii postsotsialisticheskikh obshchestv (S. 7-14). Saint-Petersburg: TSNSI.

12. Rozman, I. (2017). Dosvid rozrobky biohrafichnoho pidkhodu v riznykh haluziakh znan ta mozhlyvosti yoho vykorystannia $\mathrm{v}$ istoryko-pedahohichnomu doslidzhenni. Molod i rynok, 11 (154), 96-101.

13. Skibińska, E. (2006). Mikroświaty kobiet. Relacje autobiograficzne. Warszawa: Wydawnictwo Instytutu Technologii Eksploatacji Radom.

14. Smolinchuk, L. S. (2013). Do problemy klasyfikatsii dzherelnoi bazy doslidzhennia personalii. Pedahohichnyi dyskurs, 15, 664-668.

15. Sukhomlynska, O. V. (2005). Ukrainska pedahohika v personaliiakh. Knyha 1. Kyiv: Lybid. 